\title{
No mutations but an increased frequency of SDHx polymorphisms in patients with sporadic and familial medullary thyroid carcinoma
}

\author{
M Montani, A M Schmitt, S Schmid, T Locher, P Saremaslani, P U Heitz, \\ $P$ Komminoth ${ }^{1}$ and $A$ Perren
}

\author{
Institute for Clinical Pathology, Department of Pathology, University Hospital Zurich, Schmelzbergstr. 12, CH-8091 Zurich, \\ Switzerland \\ ${ }^{1}$ Institute for Pathology, Kantonsspital Baden, Baden, Switzerland \\ (Requests for offprints should be addressed to A Perren; Email: Aurel.Perren@usz.ch)
}

\begin{abstract}
Germline mutations of the three succinate dehydrogenase subunits $S D H B, S D H C$ and $S D H D$ have recently been associated with familial pheochromocytoma and paraganglioma. Several reasons make these genes candidate tumor suppressor genes for medullary thyroid carcinoma (MTC): (1) $S D H B$ lies on chromosome 1p, the region known to be deleted most frequently in MTC, (2) MTCs develop from neural crest-derived cells, as do pheochromocytomas and paragangliomas and (3) patients with germline mutations of the Ret-protooncogene develop MTCs as well as pheochromocytomas, indicating a relationship of these tumors on a genetic level. Therefore, we attempted to determine whether the tumor suppressor genes $S D H B, S D H C$ and $S D H D$ are involved in sporadic and familial MTC. Somatic mutations of the $S D H$ subunits were absent in all 35 investigated MTCs. Loss of heterozygosity was found in $27 \%(S D H B)$ and $4 \%(S D H D)$ respectively. While the frequency of non-coding, intronic polymorphisms did not differ in MTC patients compared with a control population, an accumulation of amino-acid coding polymorphisms (S163P in SDHB as well as G12S and H50R in SDHD) was found among MTC patients especially patients with familial tumors, suggesting a functional connection of coding $S D H$ polymorphisms to activating Ret mutations.
\end{abstract}

Endocrine-Related Cancer (2005) 12 1011-1016

\section{Introduction}

Medullary thyroid carcinomas (MTCs) account for about $10 \%$ of thyroid malignancies. Little is known about the genetics of MTC: germline mutations of the Ret-protooncogene are found in approximately $25 \%$ of all MTC patients in the setting of multiple endocrine neoplasia type 2 (MEN2). Additionally, 30 to $80 \%$ of sporadic tumors harbor somatic Ret mutations, most frequently C618Y in exon 16, at least in subclones (Eng et al. 1996, Wiench et al. 2001, Jindrichova et al. 2003). However, no causative genes in sporadic MTC lacking a Ret mutation have been described to date. Mutations of the tumor suppressor genes SDHD (Baysal et al.
2000), SDHC (Niemann \& Muller 2000) and $S D H B$ (Astuti et al. 2001) have recently been described in familial paragangliomas and pheochromocytomas. Several reasons make these genes candidate tumor suppressors for MTC: (1) allelic loss of the short and long arm of chromosome 1, the localization of $S D H B$ and $S D H C$, is found in $23 \%$ of both familial and sporadic MTCs and makes this the most frequent genomic change of these neoplasms (Mathew et al. 1987, Khosla et al. 1991, Mulligan et al. 1993), (2) MTCs share similarities with paragangliomas/ pheochromocytomas regarding their common development from neural crest-derived precursor cells, immunohistochemical phenotype and common genetic 
Table 1. Patients and results

\begin{tabular}{|c|c|c|c|c|c|c|c|c|c|c|c|c|c|}
\hline \multirow[b]{2}{*}{ No } & \multirow[b]{2}{*}{ Ret } & \multirow[b]{2}{*}{ genotype } & \multirow[b]{2}{*}{ Age } & \multirow[b]{2}{*}{ Sex } & \multicolumn{2}{|c|}{ Stage } & \multicolumn{2}{|c|}{$S D H D$} & \multicolumn{3}{|c|}{$S D H B$} & \multirow{2}{*}{$\begin{array}{l}S D H C \\
\text { intron }\end{array}$} & \multirow{2}{*}{$\begin{array}{c}\text { Ret } \\
\text { somatic }\end{array}$} \\
\hline & & & & & $\mathbf{T}$ & $\mathbf{N}$ & exon & LOH & exon & intron & LOH & & \\
\hline 1 & familial & M918T & $x$ & $\mathrm{~m}$ & $x$ & $\mathrm{~N}-$ & G12S & $\square$ & & & $\square$ & & \\
\hline 2 & familial & C634Y & 22 & $\mathrm{~m}$ & $\mathrm{~T} 1(\mathrm{~m})$ & $\mathrm{N}-$ & H50R & $\square$ & & & $\bar{x}$ & & \\
\hline 3 & familial & C620Y & 62 & $f$ & T3(m) & $\mathrm{N}+$ & & $\mathbf{\square}$ & S163P & ivs $2+33$ & $\square$ & & \\
\hline 4 & familial & C634R & 39 & $\mathrm{~m}$ & $\mathrm{~T} 1(\mathrm{~m})$ & $x$ & & $\bar{\square}$ & & ivs $2+35$ & $\square$ & & \\
\hline 5 & familial & C634F & 33 & $f$ & $\mathrm{~T} 1(\mathrm{~m})$ & $\mathrm{N}-$ & & $\square$ & & ivs $2+33$ & $\square$ & & \\
\hline 6 & familial & C634W & 49 & $\mathrm{~m}$ & T3 & $\mathrm{N}-$ & & $\square$ & & & $\mathbf{\square}$ & & \\
\hline 7 & familial & C634Y & 19 & $\mathrm{~m}$ & $\mathrm{~T} 1(\mathrm{~m})$ & $\mathrm{N}+$ & & $\square$ & & & $\overline{\mathrm{NI}}$ & & \\
\hline 8 & familial & M918T & 34 & $\mathrm{~m}$ & $\mathrm{~T} 1(\mathrm{~m})$ & $\mathrm{N}-$ & & $\mathrm{NI}$ & & & $\mathbf{\square}$ & & \\
\hline 9 & familial & $\mathrm{x}$ & 19 & $\mathrm{~m}$ & $\mathrm{~T} 1$ & $x$ & & $x$ & & & $\vec{\square}$ & & \\
\hline 10 & familial & $x$ & 31 & $f$ & $\mathrm{~T} 1(\mathrm{~m})$ & $\mathrm{N}+$ & & $\mathrm{NI}$ & & & $\mathrm{NI}$ & & \\
\hline 11 & familial & C634R & 48 & $f$ & $\mathrm{~T} 1$ & $\mathrm{~N}-$ & & $\mathrm{NI}$ & & & $\square$ & & \\
\hline 12 & familial & C634Y & 45 & $f$ & T3 & $x$ & & $\mathrm{NI}$ & & & 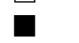 & & \\
\hline 13 & familial & $x$ & 53 & $f$ & $\mathrm{~T} 1(\mathrm{~m})$ & $\mathrm{N}-$ & & $x$ & & & $\square$ & & \\
\hline 14 & spor & - & 45 & $\mathrm{~m}$ & T3 & $\mathrm{N}+$ & H50R & $\square$ & & & $\square$ & & M918T \\
\hline 15 & spor & - & 45 & $f$ & T3 & $\mathrm{N}+$ & H50R & $\square$ & & & $\square$ & & M918T \\
\hline 16 & spor & - & 47 & $f$ & $\mathrm{~T} 2$ & $\mathrm{~N}-$ & & $\square$ & & & $\square$ & ivs2-39 & M918T \\
\hline 17 & spor & - & 62 & $f$ & $\mathrm{~T} 1(\mathrm{~m})$ & $\mathrm{N}+$ & & $\square$ & & & $\square$ & & M918T \\
\hline 18 & spor & - & 57 & $\mathrm{~m}$ & T3 & $\mathrm{N}-$ & & $\square$ & & & $\square$ & & M918T \\
\hline 19 & spor & - & 72 & $f$ & $x$ & $\mathrm{~N}+$ & & $\mathrm{NI}$ & & & $\square$ & & M918T \\
\hline 20 & spor & - & 34 & $f$ & T3 & $x$ & & $\square$ & & ivs $2+33$ & $\square$ & & M918T \\
\hline 21 & spor & - & 79 & $f$ & T2 & $\mathrm{N}-$ & & $\square$ & & & $\mathbf{\square}$ & & M918T \\
\hline 22 & spor & - & 47 & $f$ & T3 & $\mathrm{N}-$ & & $\square$ & S163P & ivs $2+33$ & $\square$ & & - \\
\hline 23 & spor & - & 56 & $\mathrm{~m}$ & T3 & $\mathrm{N}+$ & & $\square$ & & ivs $2+35$ & $\square$ & & - \\
\hline 24 & spor & - & 52 & $\mathrm{~m}$ & $x$ & $\mathrm{~N}+$ & & $\square$ & & & $\square$ & & - \\
\hline 25 & spor & - & 71 & $f$ & $\mathrm{~T} 1$ & $\mathrm{~N}-$ & & $\square$ & & & $\square$ & & - \\
\hline 26 & spor & - & 76 & $f$ & T3 & $\mathrm{N}+$ & & $x$ & & & $\overline{\mathrm{NI}}$ & & - \\
\hline 27 & spor & - & 32 & $f$ & T2 & $\mathrm{N}+$ & & $\square$ & & & $\square$ & & - \\
\hline 28 & spor & - & 42 & $\mathrm{~m}$ & T2 & $\mathrm{N}-$ & & $\square$ & & & $\square$ & & - \\
\hline 29 & spor & $x$ & 72 & $\mathrm{~m}$ & T3 & $\mathrm{N}+$ & & $x$ & & & $x$ & & - \\
\hline 30 & spor & - & 41 & $f$ & T2 & $\mathrm{N}-$ & & $\square$ & & & $\square$ & & - \\
\hline 31 & spor & - & 37 & $f$ & $\mathrm{~T} 1$ & $\mathrm{~N}-$ & & $\square$ & & & $\square$ & & - \\
\hline 32 & spor & - & 39 & $\mathrm{~m}$ & T3 & $\mathrm{N}-$ & & $x$ & & ivs $2+33$ & $\square$ & & - \\
\hline 33 & spor & - & 39 & $\mathrm{~m}$ & T3 & $\mathrm{N}+$ & & $\square$ & & & $\square$ & & - \\
\hline 34 & spor & - & 76 & $f$ & T3 & $\mathrm{N}+$ & & $\square$ & & & $\square$ & & $x$ \\
\hline 35 & spor & - & 78 & $f$ & T3 & $\mathrm{N}+$ & & $\mathrm{NI}$ & & & $\mathbf{\square}$ & & $x$ \\
\hline
\end{tabular}

$\mathrm{T}$ : tumor stage and $\mathrm{N}$ lymph node stage; - : negative; $\mathrm{x}$ : not available. $\mathrm{N}+$ : lymph node metastases; $\mathrm{N}-$ : no metastases found or no neck dissection performed; $\mathbf{\square}$ : loss of heterozygosity (LOH); $\square$ : retention of heterozygosity (ROH); NI: not informative.

background in the familial setting of MEN2, where both MTC and pheochromocytoma arise due to Ret germline mutations, and (3) an SDHD-gene germline polymorphism in exon 2 has recently been described in six members of a family with non-Ret-associated C-cell hyperplasia and hypercalcitoninemia (Lima et al. 2003). All these findings point towards a possible role of the succinate dehydrogenase $(S D H)$ genes in the tumorigenesis of MTC. The aim of our study was to investigate sporadic and familial MTC for mutations and deletions of the candidate tumor suppressor genes $S D H B, S D H C$ and $S D H D$ and to explore a possible modifying role of $S D H$ polymorphisms in MTC.

\section{Materials and methods}

Tissue specimens of 35 medullary thyroid carcinomas were included (22 sporadic and 13 MEN2 associated). Germline MEN2 status has previously been confirmed in all but 3 patients $(9,10$ and 13 (low quality DNA)) by investigation of the Ret gene (Table 1). Somatic Ret exon 16 mutations have been sought in all sporadic tumors. C-cell hyperplasia has been re-evaluated in patients 14 and 22 on a minimum of 10 calcitoninstained paraffin sections containing non-neoplastic thyroid tissue using the criteria proposed by Perry et al. (1996). Tumor tissue of 17 patients (5 MEN associated and 12 sporadic) was frozen in liquid 
nitrogen and stored at $-70^{\circ} \mathrm{C}$. The exclusive presence of tumor tissue was confirmed by controls on frozen sections prior to DNA extraction. The remaining 18 MTCs ( 8 familial and 10 sporadic), were embedded in paraffin and the tumor tissue was harvested by microdissection. Whole blood leukocytes and connective or thyroid tissues were used as non-neoplastic tissue in 20 and 14 patients respectively. No nonneoplastic tissue was available for patient no. 29 (Table 1). Blood samples from 80 unrelated Swiss individuals not suffering from endocrine disease were used as normal controls.

\section{Denaturing gradient gel electrophoresis (DGGE)-based mutation analysis}

Genomic DNA from fresh tissue (fresh frozen tumor tissue and fresh frozen non-neoplastic tissue of peripheral blood as normal controls) was isolated using the D-5000 Purgene DNA isolation kit (Gentra Systems, Minneapolis, MN, USA) according to the manufacturer's instructions. Where no fresh tissue was available, DNA was extracted from paraffin blocks for mutation and loss of heterozygosity $(\mathrm{LOH})$ analysis. For this purpose, $10-\mu \mathrm{m}$ sections were microdissected and DNA extraction was performed as described (Perren et al. 1998, Gortz et al. 1999). Primers for PCR have been designed based on Genbank sequences using the Primer 3 software (Rozen \& Skaletsky 2000); all exons as well as intron-exon boundaries have been included. PCR using genomic DNA as template was carried out in a 50- $\mu 1$ mixture of $1 \times$ PCR buffer (Perkin Elmer Europe, Rotkreuz, Switzerland) containing $400 \mathrm{ng}$ template DNA, $200 \mu \mathrm{M}$ dNTP (Roche Diagnostics, Rotkreuz, Switzerland), $1 \mu \mathrm{M}$ of each primer and $1 \mu \mathrm{l}$ Taq polymerase (Ampli Taq Gold, Perkin Elmer Europe). A touch-down procedure was used consisting of $5 \mathrm{~s}$ at $95^{\circ} \mathrm{C}$, annealing for $60 \mathrm{~s}$ at temperatures decreasing from $60^{\circ} \mathrm{C}$ to $55^{\circ} \mathrm{C}$ during the first 11 cycles (with $0.5^{\circ} \mathrm{C}$ decremental steps in cycles 2 to 11 ), and ending with an extension step at $72^{\circ} \mathrm{C}$ for $60 \mathrm{~s}$. Ten cycles with annealing temperature of $55^{\circ} \mathrm{C}$ and 15 cycles with annealing temperature of $45^{\circ} \mathrm{C}$ followed with extension times of $90 \mathrm{~s}$. After a final extension for $10 \mathrm{~min}$ at $72{ }^{\circ} \mathrm{C}$, heteroduplex formation was induced after $10 \mathrm{~min}$ denaturation at $98^{\circ} \mathrm{C}$ by incubations at $55^{\circ} \mathrm{C}$ for $30 \mathrm{~min}$ and $37^{\circ} \mathrm{C}$ for $30 \mathrm{~min}$. For DGGE analysis, $10 \mu 1$ of the PCR product were loaded with $3 \mu \mathrm{l}$ Ficoll based loading buffer onto $10 \%$ polyacrylamide gels containing a urea-formamide gradient in $0.5 \times$ TAE (tris-acetate-EDTA buffer). The amplicons were electrophoresed at $60^{\circ} \mathrm{C}$ and $100 \mathrm{~V}$ for $16 \mathrm{~h}$ with the exception of exon 1 of $S D H D$,

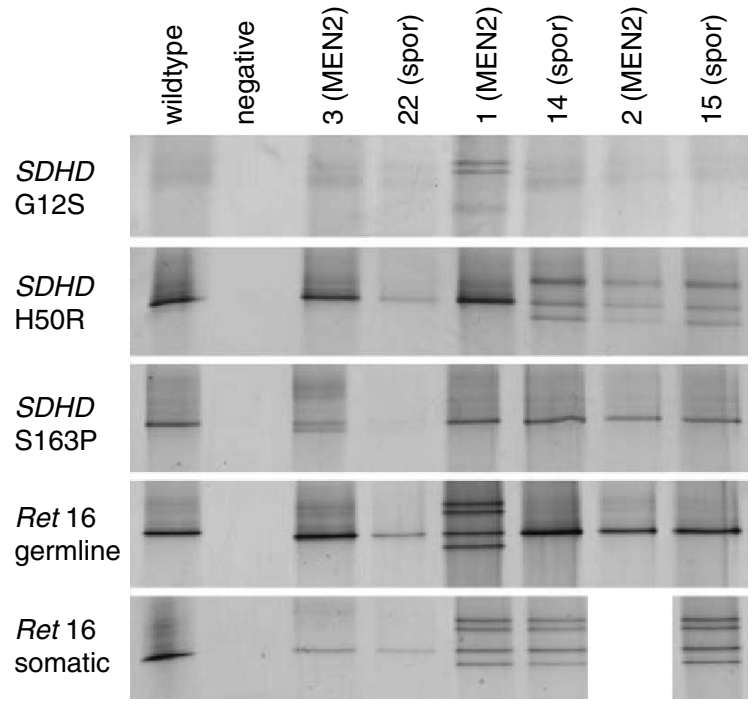

Figure 1 DGGE of $S D H D$ (exons 1 and 2), $S D H B$ (exon 5) and Ret exon 16 (tumor and control tissue) of patients with amino acid-coding polymorphisms in either $S D H D$ or SDHB. MEN2 samples lacking a somatic Ret exon 16 mutation have Ret mutations in different exons (not shown; see Table 1). spor, sporadic. Numbers above indicate patient numbers.

where the electrophoresis was run at $60 \mathrm{~V}$ for $15 \mathrm{~h}$. The fragments were visualized using silver staining as described (Komminoth et al. 1994). Samples exhibiting additional bands were cycle sequenced. Assessment of Ret status in blood cells or tumor tissue has been performed using PCR, single strand conformation polymorphism (SSCP) and DGGE as described (Komminoth et al. 1995, Marsh et al. 1997, MihicProbst et al. 2004). (Fig. 1)

\section{LOH analysis}

The genomic DNA was used to amplify the polymorphic markers D1S402 (telomeric), D1S199 and D1S2644 (centromeric) flanking the $S D H B$ gene as well as D11S900 (centromeric) and D11S1347 (telomeric) flanking the $S D H D$ gene. The forward primers were $5^{\prime}$ labeled with either HEX or 6-FAM fluorescent dyes. Fragment size analysis was performed with the 3100 Genetic Analyzer, Applied Biosystems/Hitachi and Gene-Scan software (Applied Biosystems, Foster City, CA, USA). Ratios $>2$ or $<0.5$ were designated as $\mathrm{LOH}$.

\section{Results}

Mutation analysis was performed in 35 MTCs. Due to formalin fixation and paraffin embedding, DNA could 
Table 2. Summary of SDHx polymorphisms

\begin{tabular}{|c|c|c|c|c|c|c|}
\hline \multirow[b]{3}{*}{ Alteration } & \multicolumn{3}{|c|}{ SDHB } & \multirow{3}{*}{$\frac{\text { SDHC }}{\text { Exon } 3}$} & \multicolumn{2}{|c|}{ SDHD } \\
\hline & \multicolumn{2}{|c|}{ Exon 2} & \multirow{2}{*}{$\begin{array}{l}\text { Exon } 5 \\
\text { S163P }\end{array}$} & & Exon 1 & Exon 2 \\
\hline & ivs $2+33 A>G$ & ivs $2+35 G>A$ & & & G12S & H50R \\
\hline dbSNP: rs & 2647169 & - & - & - & - & 11214077 \\
\hline MTC Sporadic & $\begin{array}{l}3 / 19 \\
(15.8 \%)\end{array}$ & $\begin{array}{l}1 / 19 \\
(5.3 \%)\end{array}$ & $\begin{array}{l}1 / 17 \\
(5.9 \%)\end{array}$ & $\begin{array}{l}1 / 20 \\
(5 \%)\end{array}$ & $0 / 22$ & $\begin{array}{l}2 / 22 \\
(9.1 \%)\end{array}$ \\
\hline MTC MEN & $\begin{array}{l}2 / 9 \\
(22.2 \%)\end{array}$ & $\begin{array}{l}1 / 9 \\
(11.1 \%)\end{array}$ & $\begin{array}{l}1 / 9 \\
(11.1 \%)\end{array}$ & $0 / 11$ & $\begin{array}{l}1 / 13 \\
(7.7 \%)\end{array}$ & $\begin{array}{l}1 / 11 \\
(9.1 \%)\end{array}$ \\
\hline $\begin{array}{l}\text { Control } \\
\text { population }\end{array}$ & $\begin{array}{l}7 / 34 \\
(20.6 \%)\end{array}$ & $\begin{array}{l}3 / 34 \\
(8.8 \%)\end{array}$ & $0 / 36$ & $0 / 37$ & $0 / 83$ & $\begin{array}{l}1 / 83 \\
(1.2 \%)\end{array}$ \\
\hline
\end{tabular}

Coding polymorphisms are indicated in bold letters. Numbers do not add up, some exons could not be amplified by PCR.

successfully be amplified by PCR (depending on the exon) in $15(42.8 \%)$ to $35(100 \%)$ tumors (see Table 2$)$. Somatic mutations were absent in all informative exons of $S D H B, S D H C$ and $S D H D$. However, 12 of 35 patients $(34.3 \%)$ showed $S D H x$ germline alterations, present in neoplastic as well as in non-neoplastic tissue.

\section{SDHB}

In intron 2 of $S D H B$, germline alterations were present in 7 of 28 patients $(25 \%)$, consisting of a nucleic acid replacement of adenine by guanine (ivs $2+33 \mathrm{~A}>\mathrm{G}$ ) in 5 patients and a guanine to adenine exchange (ivs $2+35 \mathrm{G}>\mathrm{A}$ ) in 2 patients. In exon 5 of $S D H B$, a germline thymine to cytosine nucleotide exchange leading to a serine to proline amino acid exchange at codon 163 (S163P) was detected in 1/17 (5.9\%) patients suffering from a sporadic tumor and in $1 / 9$ $(11.1 \%)$ patients suffering from familial tumors (Fig. 1). This change was absent in 36 control patients. Eight of thirty informative tumors (26.7\%) (4 familial and 4 sporadic tumors) showed a chromosomal loss of at least one polymorphic marker of the $S D H B$ locus. Two of the four sporadic MTCs with $S D H B$-LOH harbored a somatic Ret mutation. Notably, none of the patients with the above $S D H B$ germline alterations revealed an $\mathrm{LOH}$ (Table 1).

\section{$S D H D$}

A nucleotide exchange guanine to adenine, leading to a replacement of glycine by a serine on codon $12(\mathrm{G} 12 \mathrm{~S})$, was found in one of thirteen MEN2 patients $(7.7 \%)$ whereas no alterations were found in exon 1 of the SDHD gene among 22 sporadic MTC samples and 83 control samples (Fig. 1). In exon 2 a nucleotide exchange adenine to guanine, leading to a replacement of the amino-acid histidine by an arginine (H50R) was found in 2 of $22(9.1 \%)$ sporadic and in 1 of $11(9.1 \%)$ familial tumors, (Fig. 1) whereas this alteration occurred in only 1 of $83(1.2 \%)$ control samples (Table 2$)$. Twenty-four $(68.6 \%)$ patients (7 with familial and 17 with sporadic tumors) were informative for at least one polymorphic marker of the SDHD locus. Only one patient with a familial tumor showed LOH (4.2\%). This patient revealed no $S D H D$ germline alteration (Table 1).

\section{SDHC}

One intronic germline alteration on position ivs2-39, replacing thymine by cytosine (ivs2-39T $>$ C) was found in a patient with a sporadic tumor.

\section{Discussion}

We examined 35 medullary thyroid carcinomas for mutations of the three succinate dehydrogenase subunits $S D H B, S D H C$ and $S D H D$. Somatic mutations were absent both in sporadic (22 tumors) and MEN2associated MTCs (13 tumors). It is unlikely that these results represent an artifact: contamination by non neoplastic tissue can be excluded due to careful microdissection of tumor tissue and it is unlikely that significant mutations were missed, since the DGGE method is highly sensitive (Trulzsch et al. 1999). This is underlined by the detection of all reported polymorphisms in these genes. Additionally, all samples with faint additional bands have subsequently been cyclesequenced to confirm negative results. We cannot exclude large homozygous deletions or deletions encompassing single exons of the genes; however, at least in a familial setting, such alterations are reported to be rare (McWhinney et al. 2004). Hemizygous 
deletions of the $S D H B$ locus on 1p36.1-35 were detected by $\mathrm{LOH}$ analysis in a significant proportion of MTCs. Eight of thirty informative MTCs (26.7\%) showed $\mathrm{LOH}$ of at least one $1 \mathrm{p}$ marker. This finding is similar to previously published rates of $1 \mathrm{p} \mathrm{LOH}$ (Mathew et al. 1987, Khosla et al. 1991, Mulligan et al. 1993). The absence of mutations suggests that genes other than $S D H B$ are the targets of this deletion. Other mechanisms of $S D H B$ inactivation such as promotor methylation cannot be excluded by our analysis. Methylation of one $S D H B$ allele has recently been described in sporadic pheochromocytomas and neuroblastomas (Astuti et al. 2004), but this methylation did not lead to a decreased enzymatic activity and therefore seems not to be of functional significance. Only one of twenty-four informative tumors $(4.2 \%)$ revealed $\mathrm{LOH}$ of the $S D H D$ region on $11 \mathrm{q} 23$, arguing strongly against the presence of an important tumor suppressor gene for MTC on this locus. Using DGGE and sequencing, we detected seven different germline nucleic acid changes. The intronic sequence variants ivs $2+33 \mathrm{~A}>\mathrm{G}$ and ivs $2+35 \mathrm{G}>\mathrm{A}$ are known polymorphisms (Benn et al. 2003) with a reported allelic frequency of $4 \%$ and $12 \%$ respectively (Benn et al. 2003). We detected an almost identical frequency of these polymorphisms in sporadic and familial MTC patients as well as in our control individuals (Table 2). In contrast, all coding polymorphisms leading to an amino acid change (S163P in $S D H B$ as well as G12S and H50R in $S D H D$ ) detected in this study were more common in MTC patients ( 6 of $35 ; 17.1 \%$ ) than in the control population ( 1 of $83 ; 1.2 \%)$. Neoplastic C-cell hyperplasia could not be detected in patients 14 and 22 with coding polymorphisms H50R and S163P of the $S D H D$ and $S D H B$ genes. This result is in contrast to the previously published family reported by Lima et al. (2003), where the H50R variant of the SDHD gene was associated with familial $\mathrm{C}$-cell hyperplasia. It remains speculative whether, in this family, the H50R variant might exert some hitherto unknown influence on C-cell hyperplasia in a specific genetic setting. The rate of coding polymorphisms is also increased in MEN2patients $(3$ of $13 ; 23.1 \%)$ as in patients with sporadic MTC (3 of 22; 13.6\%) (Table 2). As five of six coding $S D H$ polymorphisms were associated with either a germline or a somatic Ret mutation, a functional relationship of these polymorphisms to the mutated form of the Ret gene could be possible. SDH polymorphisms might lead to hypoxia-induced apoptotic signals (Eng et al. 2003) counteracting a Ret-induced resistance to apoptosis (Maeda et al. 2004) and could therefore be more frequent in MEN2 patients. The reported coding SDHx polymorphisms could also be genetic modifiers for MTC. Such modifying genetic factors are suspected in the familial setting of MEN2, explaining a variable clinical disease penetrance (Feldman et al. 2000, Fitze et al. 2002, Lombardo et al. 2002). Studies in a mouse model of MEN2 also suggest the presence of further genes modifying penetrance and expressivity of MTCs in MEN2 (Cranston \& Ponder 2003). Further studies, including in vitro studies, are therefore needed to reveal whether coding polymorphisms of the $S D H$ genes have such a function in MTCs.

In summary, somatic mutations of the $S D H B$, $S D H C$ and $S D H D$ genes appear to be absent in both MEN2-associated and sporadic medullary thyroid carcinomas, but the accumulation of coding polymorphisms of these genes in sporadic and familial MTC patients suggests a possible role for $S D H$ polymorphisms as susceptibility/disease modifying factors in familial and sporadic MTC.

\section{Funding}

This work has been supported, in part, by the Swiss National Foundation (SNF 31-10825/1). There is no conflict of interest that would prejudice impartiality.

\section{References}

Astuti D, Latif F, Dallol A, Dahia PL, Douglas F, George E, Skoldberg F, Husebye ES, Eng C \& Maher ER 2001 Gene mutations in the succinate dehydrogenase subunit SDHB cause susceptibility to familial pheochromocytoma and to familial paraganglioma. American Journal of Human Genetics 69 49-54.

Astuti D, Morris M, Krona C, Abel F, Gentle D, Martinsson T, Kogner P, Neumann HP, Voutilainen R, Eng C et al. 2004 Investigation of the role of SDHB inactivation in sporadic phaeochromocytoma and neuroblastoma. British Journal of Cancer 91 1835-1841.

Baysal BE, Ferrell RE, Willett-Brozick JE, Lawrence EC, Myssiorek D, Bosch A, van der Mey A, Taschner PE, Rubinstein WS, Myers EN et al. 2000 Mutations in SDHD, a mitochondrial complex II gene, in hereditary paraganglioma. Science 287 848-851.

Benn DE, Croxson MS, Tucker K, Bambach CP, Richardson AL, Delbridge L, Pullan PT, Hammond J, Marsh DJ \& Robinson BG 2003 Novel succinate dehydrogenase subunit B (SDHB) mutations in familial phaeochromocytomas and paragangliomas, but an absence of somatic SDHB mutations in sporadic phaeochromocytomas. Oncogene 22 1358-1364.

Cranston AN \& Ponder BA 2003 Modulation of medullary thyroid carcinoma penetrance suggests the presence of modifier genes in a RET transgenic mouse model. Cancer Research 63 4777-4780. 
Eng C, Mulligan LM, Healey CS, Houghton C, Frilling A, Raue F, Thomas GA \& Ponder BA 1996 Heterogeneous mutation of the RET proto-oncogene in subpopulations of medullary thyroid carcinoma. Cancer Research $\mathbf{5 6}$ 2167-2170.

Eng C, Kiuru M, Fernandez MJ \& Aaltonen LA 2003 A role for mitochondrial enzymes in inherited neoplasia and beyond. Nature Reviews Cancer 3 193-202.

Feldman GL, Edmonds MW, Ainsworth PJ, Schuffenecker I, Lenoir GM, Saxe AW, Talpos GB, Roberson J, Petrucelli N \& Jackson CE 2000 Variable expressivity of familial medullary thyroid carcinoma (FMTC) due to a RET V804M (GTG $\rightarrow$ ATG) mutation. Surgery 128 93-98.

Fitze G, Schierz M, Bredow J, Saeger HD, Roesner D \& Schackert HK 2002 Various penetrance of familial medullary thyroid carcinoma in patients with RET protooncogene codon 790/791 germline mutations. Annals of Surgery 236 570-575.

Gortz B, Roth J, Speel EJ, Krahenmann A, De Krijger RR, Matias-Guiu X, Muletta-Feurer S, Rutmann K, Saremaslani P, Heitz PU et al. 1999 MEN1 gene mutation analysis of sporadic adrenocortical lesions. International Journal of Cancer 80 373-379.

Jindrichova S, Kodet R, Krskova L, Vlcek P \& Bendlova B 2003 The newly detected mutations in the RET protooncogene in exon 16 as a cause of sporadic medullary thyroid carcinoma. Journal of Molecular Medicine $\mathbf{8 1}$ 819-823.

Khosla S, Patel VM, Hay ID, Schaid DJ, Grant CS, van Heerden JA \& Thibodeau SN 1991 Loss of heterozygosity suggests multiple genetic alterations in pheochromocytomas and medullary thyroid carcinomas. Journal of Clinical Investigation 87 1691-1699.

Komminoth P, Kunz E, Hiort O, Schroder S, Matias-Guiu X, Christiansen G, Roth J \& Heitz PU 1994 Detection of RET proto-oncogene point mutations in paraffinembedded pheochromocytoma specimens by nonradioactive single-strand conformation polymorphism analysis and direct sequencing. American Journal of Pathology 145 922-929.

Komminoth P, Muletta-Feurer S, Saremaslani P, Kunz EK, Matias-Guiu X, Hiort O, Schroder S, Seelentag WK, Roth J \& Heitz PU 1995 Molecular diagnosis of multiple endocrine neoplasia (MEN) in paraffin-embedded specimens. Endocrine Pathology 6 267-278.

Lima J, Teixeira-Gomes J, Soares P, Maximo V, Honavar M, Williams D \& Sobrinho-Simoes M 2003 Germline succinate dehydrogenase subunit D mutation segregating with familial non-RET C cell hyperplasia. Journal of Clinical Endocrinology and Metabolism 88 4932-4937.

Lombardo F, Baudin E, Chiefari E, Arturi F, Bardet S, Caillou B, Conte C, Dallapiccola B, Giuffrida D, Bidart JM et al. 2002 Familial medullary thyroid carcinoma: clinical variability and low aggressiveness associated with RET mutation at codon 804. Journal of Clinical Endocrinology and Metabolism 87 1674-1680.
McWhinney SR, Pilarski RT, Forrester SR, Schneider MC, Sarquis MM, Dias EP \& Eng C 2004 Large germline deletions of mitochondrial complex II subunits SDHB and SDHD in hereditary paraganglioma. Journal of Clinical Endocrinology and Metabolism 89 5694-5699.

Maeda K, Murakami H, Yoshida R, Ichihara M, Abe A, Hirai M, Murohara T \& Takahashi M 2004 Biochemical and biological responses induced by coupling of Gabl to phosphatidylinositol 3-kinase in RET-expressing cells. Biochemical and Biophysical Research Communications 323 345-354.

Marsh DJ, Zheng Z, Arnold A, Andrew SD, Learoyd D, Frilling A, Komminoth P, Neumann HP, Ponder BA, Rollins BJ et al. 1997 Mutation analysis of glial cell line-derived neurotrophic factor, a ligand for a $\mathrm{RET} /$ coreceptor complex, in multiple endocrine neoplasia type 2 and sporadic neuroendocrine tumors. Journal of Clinical Endocrinology and Metabolism 82 3025-3028.

Mathew CG, Smith BA, Thorpe K, Wong Z, Royle NJ, Jeffreys AJ \& Ponder BA 1987 Deletion of genes on chromosome 1 in endocrine neoplasia. Nature 328 524-526.

Mihic-Probst D, Perren A, Schmid S, Saremaslani P, Komminoth P \& Heitz PU 2004 Absence of BRAF gene mutations differentiates spitz nevi from malignant melanoma. Anticancer Research 24 2415-2418.

Mulligan LM, Gardner E, Smith BA, Mathew CG \& Ponder BA 1993 Genetic events in tumour initiation and progression in multiple endocrine neoplasia type 2. Genes Chromosomes Cancer 6 166-177.

Niemann S \& Muller U 2000 Mutations in SDHC cause autosomal dominant paraganglioma, type 3. Nature Genetics 26 268-270.

Perren A, Roth J, Muletta-Feurer S, Saremaslani P, Speel EJ, Heitz PU \& Komminoth P 1998 Clonal analysis of sporadic pancreatic endocrine tumours. Journal of Pathology 186 363-371.

Perry A, Molberg K \& Albores-Saavedra J 1996 Physiologic versus neoplastic C-cell hyperplasia of the thyroid: separation of distinct histologic and biologic entities. Cancer 77 750-756.

Rozen S \& Skaletsky H 2000 Primer 3 on the www for general users and for biologist programmers. Methods in Molecular Biology 132 365-386.

Trulzsch B, Krohn K, Wonerow P \& Paschke R 1999 DGGE is more sensitive for the detection of somatic point mutations than direct sequencing. Biotechniques $\mathbf{2 7}$ 266-268.

Wiench M, Wygoda Z, Gubala E, Wloch J, Lisowska K, Krassowski J, Scieglinska D, Fiszer-Kierzkowska A, Lange D, Kula D et al. 2001 Estimation of risk of inherited medullary thyroid carcinoma in apparent sporadic patients. Journal of Clinical Oncology 19 1374-1380. 